Article

\title{
Improvement of Microbial Electrolysis Cell Activity by Using Anode Based on Combined Plasma-Pretreated Carbon Cloth and Stainless Steel
}

\author{
Shmuel Rozenfeld ${ }^{1}{ }^{(0}$, Lea Ouaknin Hirsch ${ }^{1}$, Bharath Gandu ${ }^{1}$, Ravit Farber ${ }^{1}$, Alex Schechter ${ }^{2}$ \\ and Rivka Cahan ${ }^{1, *}$ \\ 1 Department of Chemical Engineering and Biotechnology, Ariel University, Ariel 40700, Israel; \\ shmuelro@ariel.ac.il (S.R.); leaou@ariel.ac.il (L.O.H.); bharathga@ariel.ac.il (B.G.); ravitf@ariel.ac.il (R.F.) \\ 2 Department of Chemical Sciences, Ariel University, Ariel 40700, Israel; salex@ariel.ac.il \\ * Correspondence: rivkac@ariel.ac.il; Tel.: +972-54-7740293
}

Received: 14 April 2019; Accepted: 20 May 2019; Published: 23 May 2019

\begin{abstract}
The anode activity in a microbial electrolysis cell (MEC) is known to be a limiting factor in hydrogen production. In this study, the MEC was constructed using different anode materials and a platinum-coated carbon-cloth cathode (CC). The anodes were comprised of CC, stainless steel (SS), and a combination of the two (COMB). The CC and SS anodes were also treated with plasma to improve their surface morphology and hydrophilic properties (CCP and SSP, respectively). A combined version of CCP attached to SS was also applied (COMBP). After construction of the MEC using the different anodes, we conducted electrochemical measurements and examination of biofilm viability. Under an applied voltage of $0.6 \mathrm{~V}(\mathrm{Ag} / \mathrm{AgCl})$, the currents of a MEC based on CCP and COMBP were $11.66 \pm 0.1331$ and $16.36 \pm 0.3172 \mathrm{~A} \mathrm{~m}^{-2}$, respectively, which are about three times higher compared to the untreated CC and COMB. A MEC utilizing an untreated SS anode exhibited current of only $0.3712 \pm 0.0108 \mathrm{~A} \mathrm{~m}^{-2}$. The highest biofilm viability of $0.92 \mathrm{OD}_{540} \pm 0.07$ and hydrogen production rate of $0.0736 \pm 0.0022 \mathrm{~m}^{3} \mathrm{~d}^{-1} \mathrm{~m}^{-2}$ at $0.8 \mathrm{~V}$ were obtained in MECs based on the COMBP anode. To our knowledge, this is the first study that evaluated the effect of plasma-treated anodes and the use of a combined anode composed of SS and CC for hydrogen evolution in a MEC.
\end{abstract}

Keywords: microbial electrolysis cell; carbon cloth; stainless steel; cold low-pressure nitrogen plasma; Geobacter sulfurreducens; biofilm; bioanode; hydrogen production

\section{Introduction}

A microbial electrolysis cell (MEC) is an electrochemical device with a microbial anode, which operates under applied external potential. It bears some similarities to the microbial fuel cell (MFC), which operates as a galvanic cell. A MEC facilitates hydrogen generation by using a hydrogen evolution cathode instead of the oxygen reduction cathode in a MFC. On the other hand, the bioelectrochemical activity of the bioanode is the same in both devices [1,2], and is promoted by bacteria-inducing current production. The anode properties require a high surface area for biofilm formation, functional groups that will support sustainable attachment of the bacteria to the surface, and high conductivity to support effective electron transfer from the bacteria to the anode material.

There are several anode materials that are currently under research [3,4]. Carbon-based materials are cost-effective and serve as electrodes in many configurations, such as carbon cloth [5-7], carbon fibers [8], carbon brush [9], graphite-fiber brush [10], graphite granules [11], and graphite plates [12]. Highly pure graphite is chemically more stable compared to carbon (e.g., carbon cloth or carbon felt), and, despite the higher cost of high-grade graphite, it is widely used as a bioanode [13]. 
There are very few reports of carbon-free bioanodes based on highly expensive noble metals for the anode raw material, such as platinum [14], titanium [15], and stainless steel (SS) [16,17].

In order to become commercially applicable, the anode materials need to be cost-effective and chemically stable for years. In addition, there is the high importance of active biofilm on the anode. Elements influencing bacterial attachment and biofilm formation on surfaces include the bacterial cell-surface charges, capsule, flagella, fimbriae and pili. The substratum topography (scratches, pores) and hydrophilicity are also important factors influencing biofilm formation [18-21]. Modification of the substratum surface for enhancement of bacterial attachment should be cost-effective and environmentally friendly [22]. Several surface modifications to improve the anode performance include: electrochemical oxidation, heat treatment, chemical functionalization by ammonia gas or acid, as well as combinations of the above methods [3,23].

In this study, we explored anodes made of carbon cloth activated by cold nitrogen plasma, known to modify the chemical surface properties by increasing its micro-porosity and introducing nitrogen doping atoms [24]. This chemical modification also alters the hydrophilic properties of the carbon, making it more wettable and accessible to bacterial attachment. Cold nitrogen plasma was reported to produce nitrogen species on surfaces such as pyridines, amines, and pyrroles [25-28], while surface treatment by oxygen plasma leads to an increase of $-\mathrm{C}-\mathrm{OH},-\mathrm{COOH}$, and $=\mathrm{C}=\mathrm{O}$ [29]. There are very few reports of bacterial growth on anode materials which were plasma-pretreated. It was demonstrated that treatment of carbon nanotubes (CNTs) using argon plasma caused biofilm enhancement of the Gram-positive bacteria B. subtilis and S. epidermidis, while no change was observed when the Gram-negative bacteria E. coli and P. aeruginosa were used [30].

In the current study, we examined the viability of the attached biofilm on stainless-steel and carbon-cloth anode materials that were plasma-pretreated and untreated. Electrochemical measurements were performed for the MEC based on anode materials composed of carbon cloth, a combination of carbon cloth and stainless steel, as well as plasma-pretreated carbon cloth alone and in combination with stainless steel. To our knowledge, this is the first study that evaluates the effect of cold low-pressure nitrogen plasma on MEC electrochemical performance.

\section{Materials and Methods}

\subsection{Bacterial Strain and Preparation of Bacterial Anode}

A pure culture of Geobacter sulfurreducens (DSMZ 12127) was grown on Geobacter medium ( $\mathrm{N}^{\prime} 826$, DSMZ Germany), in a $80 \% \mathrm{~N}_{2}: 20 \% \mathrm{CO}_{2}$ atmosphere, in 50 borosilicate glass serum bottles with a $20 \mathrm{~mm}$ butyl septum (Wheaton Glass Co, USA) for about 7-10 days, until significant bacterial red aggregates were settled on the bottom of the bottle [31]. A portion of medium containing a high bacterial concentration was vigorously agitated for suspension of the bacteria. The optical density (OD) was measured using a GENESYS $10 \mathrm{~S}$ UV-visible spectrophotometer (Thermo, Madison, WI, USA) at $590 \mathrm{~nm}\left(\mathrm{OD}_{590}\right)$. A single-chamber MEC was inoculated with $G$. sulfurreducens to a final $\mathrm{OD}_{590}$ of about $0.35 \mathrm{OD} \pm 0.05$.

\subsection{Cold Low-Pressure Nitrogen Plasma Treatment of Carbon-Cloth and Stainless-Steel Anode Materials}

The carbon-cloth (CC) and stainless-steel (SS) anode materials were treated with cold nitrogen plasma using a PDC-32G-2 (Harrick, Ithaca, NY, USA) plasma system (RF of $60 \mathrm{~Hz}$, power of $18 \mathrm{~W}$ ) for 2 min at a pressure of 2 torr. Nitrogen at $99.999 \%$ purity was supplied by Oxygen and Argon Works Ltd., Israel. Immediately after the cold nitrogen plasma treatment, the anodes were placed in distilled water to preserve their surface activation [32]. 


\subsection{MEC Setup}

The single-chamber MEC consisted of a $250 \mathrm{~mL}$ borosilicate bottle, with a GL45 open cap including a double-layer silicone/PTFE septum. The MEC was filled with $200 \mathrm{~mL}$ of $90 \%$ Geobacter medium ( $\mathrm{N}^{\prime} 826$, DSMZ Germany) and 10\% $1 \mathrm{M}$ phosphate buffer (final concentration of $100 \mathrm{mM}$, $\mathrm{pH}$ 6.8). There were four MECs which each contained several types of anode electrodes: CC (E-TEK W1400 LT, USA), carbon cloth that was plasma-pretreated (CCP), SS (316L, 80 mesh, INOXIA, UK), stainless steel that was plasma-pretreated (SSP), a combination of SS and CC designated as COMB, and a combination of SS and CCP designated as COMBP. Each of them had the same geometric area of $6.25 \mathrm{~cm}^{2}(2.5 \mathrm{~cm} \times 2.5 \mathrm{~cm})$. The electrodes were fixed tightly to each other by stitching at several points. The cathode electrode was made of carbon cloth coated by $0.5 \mathrm{mg} \mathrm{cm}^{-2} \mathrm{Pt} / 60 \%$ on carbon support (CTM-GDE-02, FuelCellsEtc, USA), with a geometric area of $6.25 \mathrm{~cm}^{2}(25 . \mathrm{cm} \times 2.5 \mathrm{~cm})$ and an $\mathrm{Ag} / \mathrm{AgCl}$ reference electrode (RE-1CP, ALS, Japan). The MEC was placed in a thermostatic bath at $35^{\circ} \mathrm{C}$ and operated under a constant potential of $0.3 \mathrm{~V}$ (versus an $\mathrm{Ag} / \mathrm{AgCl}$ reference electrode) using a potentiostat (Ivium N-stat, Netherlands). Measurements were performed at a range of potentials, as described in each experiment. Examination of the attached biofilm viability was done using 3-(4,5-dimethylthiazol-2-yl)-2,5-diphenyltetrazolium bromide (MTT) calorimetric analysis and conducted for the anode materials before as well as at the end of the MEC operation [33].

\subsection{Electrochemical Measurements}

\subsubsection{Linear Sweep Voltammetry (LSV) Measurement}

LSV measurement was performed in a MEC using a potentiostat by a three-electrode configuration type, with a carbon cloth coated by $\mathrm{Pt}$ as a counter electrode, $\mathrm{Ag} / \mathrm{AgCl}$ as a reference electrode and the working electrode was the examined bio-anodes (Figure 1). The applied potential range was $-0.5 \mathrm{~V}$ to $0.8 \mathrm{~V}$, versus $\mathrm{Ag} / \mathrm{AgCl}$ increase in a scan rate of $5 \mathrm{mV} \mathrm{s}^{-1}[31,34,35]$.

\subsubsection{Differential Pulse Voltammetry (DPV) Measurement}

DPV was performed in a MEC in a three-electrode configuration, electrochemical cell controlled by a potentiost $[34,36,37]$. A carbon cloth coated with $\mathrm{Pt}$ was used as a counter electrode, $\mathrm{Ag} / \mathrm{AgCl}$ as a reference electrode and one of the examined bio-anodes as the working electrode. The measurement was performed by applying 14 potential steps from $-0.5 \mathrm{~V}$ to $0.8 \mathrm{~V}$ vs. $\mathrm{Ag} / \mathrm{AgCl}$. The potential in each step was maintained constant for $600 \mathrm{~s}$. The average of the measured currents on each of the applied potential steps is shown in Figure 2.

\subsection{Biofilm Viability Measurements}

\subsubsection{Biofilm Viability Depending on Anode Materials and Plasma Treatment}

G. sulfurreducens capability to produce biofilm on the varied anode materials (CC, CCP, SS, SSP, COMB, COMBP) was examined using MTT analysis, based on the bacterial hydrogenase's reduction of the tetrazolium regent. Whereas in its oxidized form the tetrazolium solution is yellow, in its reduced form it turns to blue. The intensity of the blue color can be measured in a spectrophotometer at $540 \mathrm{~nm}$ $\left(\mathrm{OD}_{540}\right)$. Each anode material (a sample of $1 \mathrm{~cm}^{2}$ ) was inserted into a vial of $10 \mathrm{~mL}$ with $5 \mathrm{~mL}$ of Geobacter medium in an $80 \% \mathrm{~N}_{2}: 20 \% \mathrm{CO}_{2}$ atmosphere, including sodium acetate $(15 \mathrm{mM})$ as an electron donor and sodium fumarate $(50 \mathrm{mM})$ as an electron acceptor. A pure culture of $G$. sulfurreducens was inoculated into the vials $(0.2-0.3$ final OD at $590 \mathrm{~nm})$ for 10 days at $35^{\circ} \mathrm{C}$, with a slow horizontal agitation. The media including planktonic bacteria was removed without opening the vial, using a needle and gas sparging pressure $\left(80 \% \mathrm{~N}_{2}: 20 \% \mathrm{CO}_{2}\right)$. The anode with the attached biofilm was washed three times with phosphate buffer saline (PBS) to remove the planktonic bacterial cells. Then, $2 \mathrm{~mL}$ of MTT solution (0.5 mg mL ${ }^{-1}$ in $0.1 \mathrm{M}$ PBS, pH 7.4, in $80 \% \mathrm{~N}_{2}: 20 \% \mathrm{CO}_{2}$ atmosphere) was added to the vials and left for $2 \mathrm{~h}$ at room temperature in the dark. The MTT solution was then removed and 
replaced by a $2 \mathrm{~mL}$ solution of dimethyl sulfoxide:EtOH (1:1 ratio) for $20 \mathrm{~min}$. The absorbance of the solution was examined using a spectrophotometer at $\mathrm{OD}_{540}$, and the absorption was normalized to $1 \mathrm{~cm}^{2}$ of the electrode area [33].

\subsubsection{Biofilm Viability on Anodes after 30 Days of MEC Operation}

Examination of the biofilm viability on CC, CCP, COMB, and COMBP anodes was performed at the end of MEC operation in anoxic conditions, using MTT analysis. Each anode $\left(6.25 \mathrm{~cm}^{2}\right)$ with the attached biofilm was washed three times with PBS to remove the planktonic bacteria. The anode was transferred to $50 \mathrm{~mL}$ tubes containing $15 \mathrm{~mL}$ of MTT solution and was incubated for $2 \mathrm{~h}$ at room temperature in the dark. Then the MTT solution was removed and replaced by $15 \mathrm{~mL}$ of dimethyl sulfoxide:EtOH solution (1:1 ratio) for $20 \mathrm{~min}$. The absorbance of the solution was examined using a spectrophotometer at $\mathrm{OD}_{540}$. The absorbance results corresponded to a $6.25 \mathrm{~cm}^{2}$ electrode area.

\subsection{Statistics}

Data are expressed as means \pm STDEV (standard deviation) of between four to six replicates. The results were statistically analyzed using one-way analysis of variance (ANOVA). Differences between the values were considered significant at $p$-value $<0.05$.

\section{Results and Discussion}

\subsection{LSV Measurements of the Bioanodes}

Low hydrogen production in MECs is mostly related to the bacterial anode activity. The limitations of the bioanode are attributed to the bacterial attachment, biofilm development, and handling of electroactive biofilm for a prolonged period [7]. The anode material should be highly conductive, support the biofilm attachment, be chemically stable and cost-effective. Recently, it was reported that the performance of MFCs which were equipped with cost-effective anodes made of different carbon materials (carbon felt, foam, and cloth) demonstrated that the carbon felt anode was the most efficient whereas the least efficient was the carbon cloth. Performance seems to be in direct relationship with the specific area of the anode materials [38-42]. We examined a new concept of microbial anode made of carbon cloth which differs in two ways: the carbon cloth anode was attached to a rigid conductive stainless-steel material, and the carbon cloth anode was also modified by plasma irradiation.

In this study, SS anode material, which is known as a highly conductive and cost-effective metal, was compared to the common CC anode [43]. The anode materials SS and CC were used separately, and also in a combined anode configuration in which the CC and SS were tightly attached (COMB). In addition, the CC and SS were also treated with cold low-pressure plasma, producing CCP and SSP. Since SSP was found to corrode in MEC under $0.3 \mathrm{~V}$, most of the study was conducted with untreated SS; thus, the combined anode configuration, COMBP, was comprised of untreated SS and plasma-treated CC. The MECs were inoculated with Geobacter and were operated under a chronoamperometry potential of $0.3 \mathrm{~V}$ vs. $\mathrm{Ag} / \mathrm{AgCl}$. LSV measurement was performed on the 10th day of the MEC operation (Figure 1).

The results in Figure 1 show that MEC utilizing plasma-pretreated anodes (CCP and COMBP) produced higher currents compared to MECs based on untreated anodes (SS, CC and COMB). Under an applied voltage of $0.6 \mathrm{~V}$ vs. $\mathrm{Ag} / \mathrm{AgCl}$, the currents obtained in a $\mathrm{MEC}$ based on CCP and COMBP were $11.66 \pm 0.1331$ and $16.36 \pm 0.3172 \mathrm{~A} \mathrm{~m}^{-2}$, respectively; while MEC based on untreated carbon cloth (CC and COMB) yielded currents of only $3.272 \pm 0.1792$ and $5.541 \pm 0.1705 \mathrm{~A} \mathrm{~m}^{-2}$, respectively. In the MEC with a SS anode, the observed current was only $0.3712 \pm 0.0108 \mathrm{~A} \mathrm{~m}^{-2}$ at an applied voltage of $0.6 \mathrm{~V}$. 


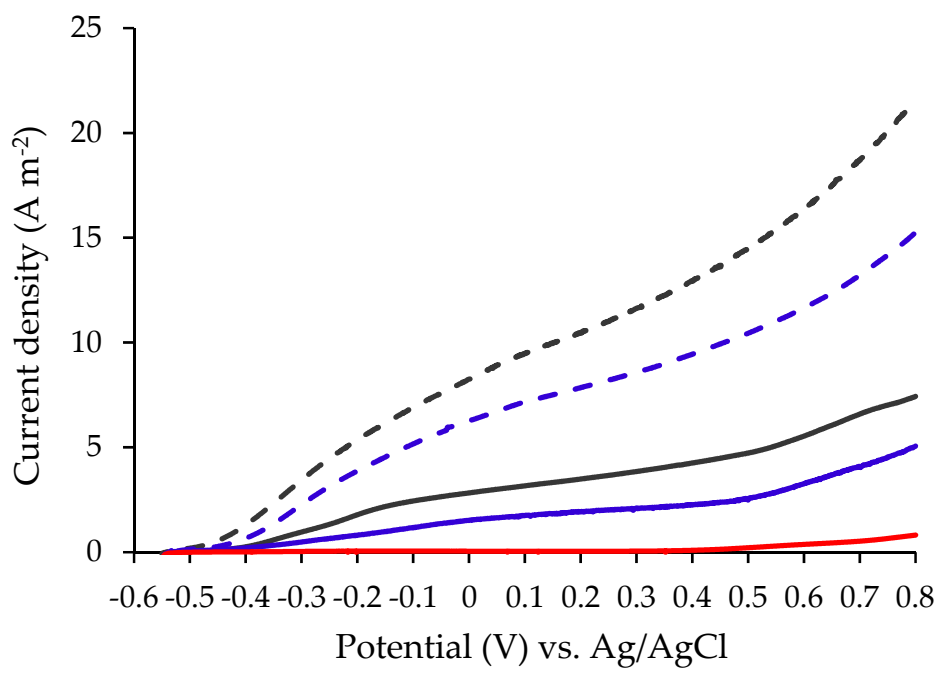

Figure 1. Linear Sweep Voltammetry (LSV) polarization curves for a bacterial anode made of CC ( - ),

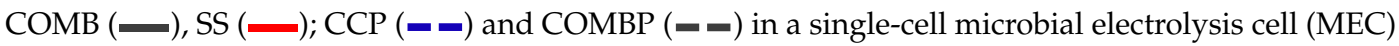
containing Geobacter medium and $0.1 \mathrm{M} \mathrm{PB}, \mathrm{pH}$. Scan rate was $5 \mathrm{mV} \mathrm{s}^{-1}$ versus $\mathrm{Ag} / \mathrm{AgCl}$.

From the LSV analysis, it can be demonstrated that plasma-pretreated anodes (CCP and COMBP) led to higher currents when compared to the untreated anodes (CC and COMB). In addition, both the combined anode COMB as well as COMBP exhibit higher currents than any of the anode materials alone (CC or SS, as well as CCP or SS, respectively). The poor biofilm viability observed on SS (further displayed and discussed in Figure 4) led us to conclude that the SS electrode mainly served as an electron-current collector, rather than a material capable of supporting biofilm attachment. However, the electron conduction through the carbon-cloth electrode strongly depended on the contact between the carbon fibers (woven or nonwoven). Thus, high conductivity (low resistance) was typically attained by applying external pressure to force good contact among the fibers, a common practice in other fuel cells (e.g., hydrogen polymer electrolyte membrane fuel cells [44,45]). Typically, in a MEC, the anode is immersed in the medium without a mechanism to press the anode's carbon material. In our study, instead of pressing the anode to increase conductivity, a highly rigid SS electrode mesh was attached to the CC to form the COMB anode. We assumed that this contact between the two anode materials provided better conditions for biofilm formation on the CC, while the SS supported better current collection through the CC by improving the electron flow toward the anode.

\subsection{DPV Measurements of the Bioanodes}

The MEC based on the SS anode led to very low currents of about only $16 \%$ and $11 \%$ of the currents obtained by CC and COMB, respectively (Figure 1). In addition, the SSP was corroded under applied voltage of $0.3 \mathrm{~V}$. This study therefore continued by using only the CC, CCP, COMB and COMBP anodes. Each one of four single-cell MECs contained the four different anodes connected to one cathode (i.e., four replicates of each anode). The MECs were operated under a constant applied potential of $0.3 \mathrm{~V}$ vs. $\mathrm{Ag} / \mathrm{AgCl}$. DPV was measured separately for each anode, one at a time, by connecting the examined anode to the cathode while the other anodes were operated in OCP mode. The DPV method provides a steady-state potentiostatic view of the current potential relationship. On the 14th day of MEC operation, a steady-state polarization curve emerged in a set of 14 potentials (between $-0.5 \mathrm{~V}-0.8 \mathrm{~V}$ vs. $\mathrm{Ag} / \mathrm{AgCl}$ ) that were measured by the DPV method (Figure 2). 


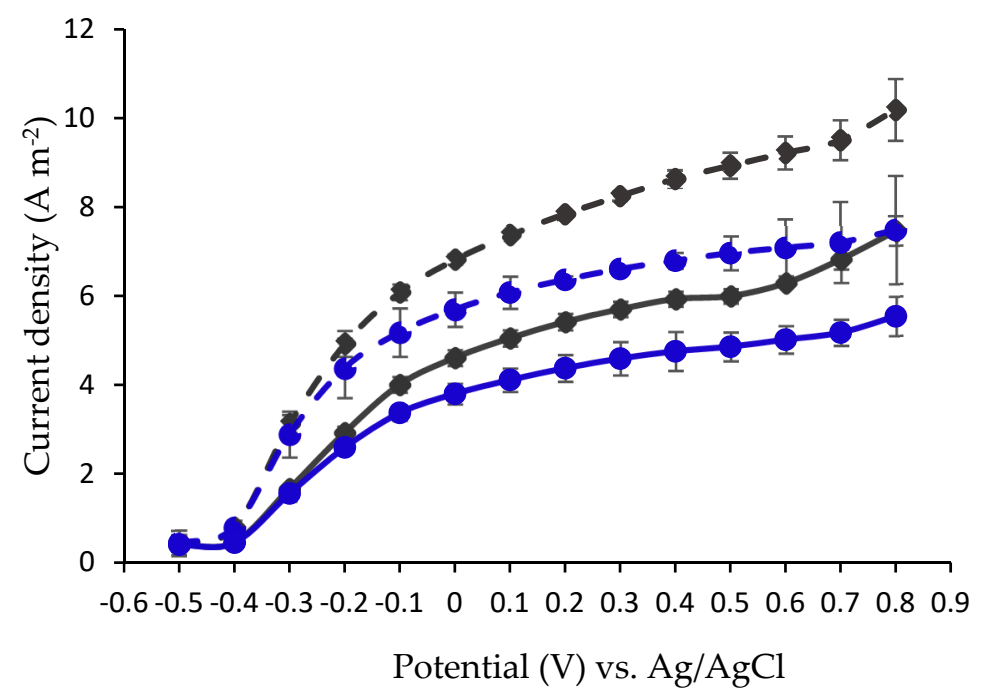

Figure 2. Differential Pulse Voltammetry (DPV) measurement of oxidation currents under 14 steps of applied voltages from $-0.5 \mathrm{~V}$ to $0.8 \mathrm{~V}$ vs. $\mathrm{Ag} / \mathrm{AgCl}$ (each step lasted $600 \mathrm{~s}$ ), in MECs based on different

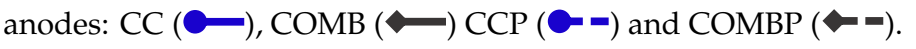

Figure 2 depicts the highest current value as $10.18 \pm 0.6958 \mathrm{~A} \mathrm{~m}^{-2}(0.8 \mathrm{~V}$ vs. $\mathrm{Ag} / \mathrm{AgCl})$ in the MEC applying a COMBP anode. Under an applied voltage of $0.6 \mathrm{~V}$, the obtained currents were $5.02 \pm 0.3083$, $6.29 \pm 0.054,7.08 \pm 0.6372$ and $9.22 \pm 0.3711 \mathrm{~A} \mathrm{~m}^{-2}$ in MECs based on anode materials of CC, COMB, CCP and COMBP, respectively.

It is very difficult to compare results from other studies regarding MEC/MFC, since there are many parameters differentiating between the reported devices (for example: electrode materials, distance between electrodes, MEC/MFC configuration, reactor volume, carbon source, and bacterial community). Several MEC/MFC studies reported using SS-anode material whose surface was treated with a method other than plasma. A tubular MEC based on a pleated SS-felt anode and a platinum cathode was reported to have low internal resistance and high conductivity of the electrodes. The MEC reached a maximum current density of $1.09 \pm 0.04 \mathrm{~mA} \mathrm{~cm}^{-2}$ at $1 \mathrm{~V} \mathrm{vs.} \mathrm{Ag} / \mathrm{AgCl}$ [46]. In that report, the SS that served as an anode in the MEC was cleaned with a mixture of ethanol and acetone to dissolve organic materials, and with a solution of fluoridric/nitric acids to dissolve the oxide layer. At an applied voltage of $0.2 \mathrm{~V}$, their reported MEC based on the clean SS showed a current density of around $0.7 \mathrm{~A} \mathrm{~m}^{-2}$ and $2.4 \mathrm{~A} \mathrm{~m}^{-2}$ with $5 \mathrm{mM}$ and $10 \mathrm{mM}$ acetate, respectively [16].

A MFC based on a $25 \mathrm{~cm}^{2}$ area of projected SS grids, which were cleaned by immersion in a $2 \% \mathrm{HF} / 0.5 \mathrm{M} \mathrm{HNO}_{3}$ solution, led to an efficient microbial anode that provided a current density of $8 \mathrm{~A} \mathrm{~m}^{-2}$ at $-100 \mathrm{mV}$ (SCE) [47]. Enhancement of biocompatibility and anode electroactivity was observed in a MFC utilizing flame oxidation of SS felt coated by iron-oxide nanoparticles (IONPs). This SS felt produced a maximum current density of $27.42 \mathrm{~mA} \mathrm{~cm}^{-3}$ and $1.92 \mathrm{~mA} \mathrm{~cm}^{-2}$ at $-0.2 \mathrm{~V}$, which was 16.5 and 4.8 times higher than the untreated SS felt and carbon felt, respectively [48].

The most commonly used anode material in MECs is CC. It was reported that in a single-cell MEC utilizing a carbon-felt anode and a Pt gas-diffusion cathode, where a J-cloth was separating the adjacent electrodes, the obtained current was $6 \mathrm{~A} \mathrm{~m}^{-2}$ under an applied voltage of $1 \mathrm{~V} \mathrm{[49].} \mathrm{A} \mathrm{multi-electrode}$ MEC stack design with increasing electrode pairs (up to 10 electrode pairs) in which activated carbon cloth (pretreated with surfactant) and SS mesh served as anode and cathode, respectively, was compared for electric current and COD reduction. A maximum current density of $520 \mathrm{~A} \mathrm{~m}^{-3}$ at an applied voltage of $1.1 \mathrm{~V}$ was observed in the 10-pair MEC compared to the single-pair MEC with a current density of $45 \mathrm{~A} \mathrm{~m}^{-3}$. These results showed that increasing the number of electrodes in MECs can magnify the current production [50]. Single-chamber MECs based on a type-A commercial carbon-cloth anode (without a wet-proofing coating) and a type-B carbon-cloth cathode ( $30 \%$ wet-proofing), separated by 
J-cloth, were inoculated by a mixed culture. Under an applied voltage of $0.6 \mathrm{~V}$, the MEC achieved a current density of $9.3 \mathrm{~A} \mathrm{~m}^{-2}$ at $\mathrm{pH} 7$ and $14 \mathrm{~A} \mathrm{~m}^{-2}$ at $\mathrm{pH} 5.8$ [51].

In summary, the reported MECs/MFCs utilizing SS anodes had high current performance. However, in our study the MEC based on SS led to a negligible current density of $0.3712 \pm 0.3711 \mathrm{~A} \mathrm{~m}^{-2}$ at an applied voltage of $0.6 \mathrm{~V}$. SS that was plasma-treated to increase hydrophilicity was corroded under an applied potential of $0.3 \mathrm{~V}$. However, a combined anode of SS and CCP (COMBP) demonstrated a high current density of $16.36 \pm 0.3172 \mathrm{~A} \mathrm{~m}^{-2}$.

3.3. Examination of the Oxidation Currents Contributed by the Planktonic Bacteria and by the Biofilm Anode in MECs Based on: CC, COMB, CCP, and COMBP

The current contributed by each of the different active elements of the MEC to the overall obtained current was determined at the end of the MEC operation period. The oxidation currents generated by the full MEC construction were measured on the 21st day. The biofilm anode was transferred to a sterile MEC to examine currents contributed by the biofilm (the "biofilm anode"). A sterile anode was inserted into the MEC with the planktonic bacteria to measure the contribution of the planktonic bacteria to the obtained current of the full MEC (the "planktonic bacteria"). In addition, at the beginning of the MEC operation, the currents were measured before inoculation (the "abiotic anode"). The currents were measured when the MECs were operated under selected voltages of between $0.2 \mathrm{~V}$ to $0.8 \mathrm{~V}$ (Table 1 ).

Table 1. Recorded currents under applied voltages of $0.2 \mathrm{~V}-0.8 \mathrm{~V}$. vs. Ag/AgCl, from MECs based on the different anodes (COMBP, COMB, CCP and CC). Measurements were collected from the fully constructed MEC, the biofilm anode, the planktonic bacteria and the abiotic anode.

\begin{tabular}{|c|c|c|c|c|c|}
\hline Electrode & Current Source & $\begin{array}{c}0.2 \mathrm{~V} \\
\text { Current (mA) }\end{array}$ & $\begin{array}{c}0.4 \mathrm{~V} \\
\text { Current (mA) }\end{array}$ & $\begin{array}{c}0.6 \mathrm{~V} \\
\text { Current (mA) }\end{array}$ & $\begin{array}{c}0.8 \mathrm{~V} \\
\text { Current (mA) }\end{array}$ \\
\hline \multirow{4}{*}{ СОМВР } & Full MEC & 4.6 & 5.01 & 5.593 & 6.807 \\
\hline & Biofilm & 1.238 & 1.651 & 2.931 & 4.861 \\
\hline & Planktonic & 0.128 & 0.224 & 0.45 & 1.112 \\
\hline & Abiotic electrode ${ }^{1}$ & 0.007 & 0.015 & 0.034 & 0.063 \\
\hline \multirow{4}{*}{ СОМВ } & Full MEC & 3.672 & 4.188 & 4.948 & 6.681 \\
\hline & Biofilm & 0.635 & 0.80 & 1.154 & 2.032 \\
\hline & Planktonic & 0.08 & 0.152 & 0.426 & 0.985 \\
\hline & Abiotic electrode ${ }^{1}$ & 0.015 & 0.069 & 0.086 & 0.097 \\
\hline \multirow{4}{*}{ ССР } & Full MEC & 3.855 & 4.221 & 4.724 & 5.273 \\
\hline & Biofilm & 0.653 & 0.704 & 1.571 & 2.763 \\
\hline & Planktonic & 0.067 & 0.108 & 0.269 & 0.818 \\
\hline & Abiotic electrode ${ }^{1}$ & 0.006 & 0.011 & 0.021 & 0.049 \\
\hline \multirow{4}{*}{$\mathrm{CC}$} & Full MEC & 2.754 & 3.15 & 3.817 & 5.270 \\
\hline & Biofilm & 0.52 & 0.641 & 0.813 & 1.334 \\
\hline & Planktonic & 0.029 & 0.03 & 0.063 & 0.167 \\
\hline & Abiotic electrode ${ }^{1}$ & 0.002 & 0.004 & 0.016 & 0.045 \\
\hline
\end{tabular}

${ }^{1}$ Abiotic electrode: Sterile anode inserted into a sterile medium as an experimental control.

The MECs based on the different anodes were operated for 14 days. Increasing the voltage from $0.2 \mathrm{~V}$ to $0.8 \mathrm{~V}$ vs. $\mathrm{Ag} / \mathrm{AgCl}$ led to higher currents in the four MECs (based on COMBP, COMB, CC, $\mathrm{CCP}$ anodes) as well as in each element (biofilm anode, planktonic bacteria, and abiotic electrode). The currents obtained under an applied voltage of $0.6 \mathrm{~V}$ from the MEC based on the COMBP anode were the highest $(5.593 \mathrm{~mA} \pm 0.067)$, while the currents obtained from the MEC based on COMB, 
CC, and CCP were $4.9480 .152,3.817 \pm 0.209$, and $4.724 \pm 0.054 \mathrm{~mA}$, respectively. In all cases, the biofilm anode contributed higher currents than the planktonic bacteria. For example, in the MEC based on the COMBP anode under an applied voltage of $0.6 \mathrm{~V}$, the biofilm anode led to a current of $2.931 \mathrm{~mA} \pm 0.056$, while the planktonic bacteria produced only $0.450 \pm 0.005 \mathrm{~mA}$. In the MEC based on the COMB anode, the biofilm anode led to a current of $1.154 \pm 0.035 \mathrm{~mA}$, while the planktonic bacteria led to only $0.426 \pm 0.013 \mathrm{~mA}$. The sum total of the currents obtained from the planktonic bacteria and from the biofilm anode did not equal the total current exhibited in the full constructed MEC. We ascribe this phenomenon to damage occurring to the bacterial anode while moving it to a sterile MEC.

\subsection{Hydrogen Formation in the MECs}

In the following experiments, we examined the effect of the anode materials and surface plasma-pretreatment of the carbon cloth to improve the hydrogen evolution reaction (HER) activity. For these measurements (Figure 3), the MECs were connected to the potentiostat in a configuration of two electrodes (the working electrode was connected to the platinized carbon cloth while the reference and counter electrodes were connected to the bacterial anode).

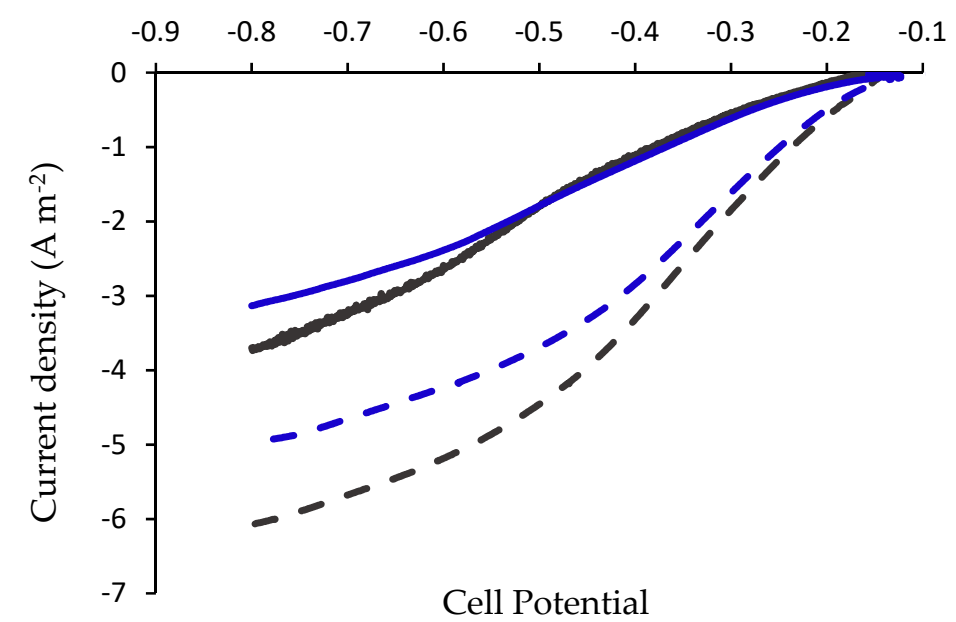

Figure 3. LSV polarization curves for a cathode in a MEC based on anodes made of CC (-), COMB

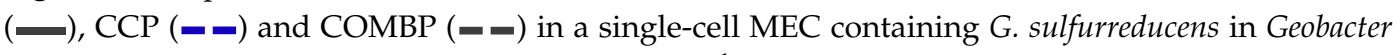
medium and $0.1 \mathrm{MPB}, \mathrm{pH}$ 7. Scan rate was $5 \mathrm{mV} \mathrm{s}^{-1}$.

The results depicted in Figure 3 show that the highest hydrogen reduction current was obtained in the MEC applying the combined anode, COMBP. At the maximal applied cell voltage $(0.8 \mathrm{~V})$ the reduction current obtained in the MEC based on a COMBP anode was $6.08 \pm 0.182 \mathrm{~A} \mathrm{~m}^{-2}$, while in the MEC based on a COMB anode the current was only $3.7 \pm 0.131 \mathrm{~A} \mathrm{~m}^{-2}$ (an improvement of $64 \%$ ). Similar results were obtained in the MEC based on plasma-treated CCP, where the reduction current was $59 \%$ higher than the current in the MEC based on the untreated anode (CC).

Calculation of hydrogen evolution rates under applied constant potentials ranging from 0.2 to $0.8 \mathrm{~V}$ were performed according to Equations (1)-(3) and results are presented in Table 2. Under an applied voltage of $0.6 \mathrm{~V}$, the current densities obtained in the MECs based on CC, COMB, CCP or COMBP anodes were $2.386 \pm 0.074,2.590 \pm 0.084,4.232 \pm 0.104$, and $5.186 \pm 0.163 \mathrm{~A} \mathrm{~m}^{-2}$, respectively. In these MECs, the hydrogen evolution rates per cubic meter of the anodic medium were $0.0902 \pm 0.0028,0.0980 \pm 0.0032,0.1600 \pm 0.004$, and $0.1961 \pm 0.006 \mathrm{~m}^{3} \mathrm{~d}^{-1} \mathrm{~m}^{-3}$, respectively. The hydrogen evolution rates per square meter of anode were $0.0289 \pm 0.0009,0.0313 \pm 0.0010$, $0.0512 \pm 0.0013$, and $0.0627 \pm 0.002 \mathrm{~m}^{3} \mathrm{~d}^{-1} \mathrm{~m}^{-2}$, respectively. These results show that under applied voltages of $0.6 \mathrm{~V}$, the MEC based on the combined anode (COMBP) led to a higher hydrogen evolution 
rate of $0.0627 \pm 0.002 \mathrm{~m}^{3} \mathrm{~d}^{-1} \mathrm{~m}^{-2}$, which is a two-fold increase over the rates of HER in the MECs based on CC and COMB. But it was only a 1.23-fold increase compared to CCP.

$$
\mathrm{V}_{\mathrm{H}_{2}}=\frac{\mathrm{I} \times \mathrm{t} \times \mathrm{R} \times \mathrm{T}}{\mathrm{z} \times \mathrm{F} \times \mathrm{P}}
$$

where $\mathrm{V}_{\mathrm{H}_{2}}-$ Hydrogen production volume $\left(\mathrm{m}^{3} \mathrm{~s}^{-1}\right), \mathrm{P}$-gas pressure $(\mathrm{atm}), \mathrm{V}$-gas volume $\left(\mathrm{m}^{3}\right)$, $\mathrm{z}$-valence of element, $\mathrm{R}$-the gas constant $\left(0.0820577 \mathrm{~L}\right.$ atm $\left(\mathrm{mol}^{-1} \mathrm{~K}^{-1}\right)$, $\mathrm{T}$-gas temperature $(\mathrm{K})$, I-current $(\mathrm{A})$, t-time (s), and F-Faraday's constant $\left(96,485 \mathrm{C} \mathrm{mol}^{-1}\right)$.

$$
\mathrm{Q}\left(\mathrm{V}_{\mathrm{r}}\right)_{\mathrm{H}_{2}}=\mathrm{V}_{\mathrm{H}_{2}}\left(\mathrm{~m}^{3}\right) \times \mathrm{t}\left(\mathrm{d}^{-1}\right) \times \mathrm{V}_{\mathrm{r}}\left(\mathrm{m}^{-3}\right)
$$

where $\mathrm{Q}\left(\mathrm{V}_{\mathrm{r}}\right)_{\mathrm{H}_{2}}-\mathrm{HER}$ production rate per cubic meter of the anodic medium, $\mathrm{V}_{\mathrm{H}_{2}}-$ Hydrogen production volume $\left(\mathrm{m}^{3} \mathrm{~s}^{-1}\right.$, calculated from Equation (1)), t-time in seconds normalized to $24 \mathrm{~h}$, and $\mathrm{V}_{\mathrm{r}}$-reactor volume normalized to cubic meter $\left(\mathrm{m}^{3}\right)$.

$$
\mathrm{Q}\left(\mathrm{A}_{\mathrm{e}}\right)_{\mathrm{H}_{2}}=\mathrm{V}_{\mathrm{H}_{2}}\left(\mathrm{~m}^{3}\right) \times \mathrm{t}\left(\mathrm{d}^{-1}\right) \times \mathrm{A}_{\mathrm{e}}\left(\mathrm{m}^{-2}\right)
$$

where $\mathrm{Q}\left(\mathrm{A}_{\mathrm{e}}\right)_{\mathrm{H}_{2}}-\mathrm{HER}$ production rate per square meter of electrode, $\mathrm{V}_{\mathrm{H}_{2}}-$ Hydrogen production volume $\left(\mathrm{m}^{3} \mathrm{~s}^{-1}\right.$, calculated from Equation (1)), t-time in seconds normalized to $24 \mathrm{~h}$, and $\mathrm{A}_{\mathrm{e}}$-electrode

\begin{tabular}{|c|c|c|c|c|}
\hline Anode & $\begin{array}{l}\text { Applied Voltage } \\
\text { (V) }\end{array}$ & $\begin{array}{c}\text { HER Current } \\
\text { Density }\left(\mathrm{A} \mathrm{m}^{-2}\right)\end{array}$ & $\begin{array}{l}\text { HER Production Rate } \\
\mathbf{Q}\left(\mathrm{V}_{\mathrm{r}}\right)_{\mathbf{H}_{2}}\left(\mathrm{~m}^{3} \mathrm{~d}^{-1} \mathrm{~m}^{-3}\right)\end{array}$ & $\begin{array}{c}\text { HER Production Rate } \\
\mathbf{Q}\left(\mathrm{A}_{\mathbf{e}}\right)_{\mathrm{H}_{2}}\left(\mathrm{~m}^{3} \mathrm{~d}^{-1} \mathrm{~m}^{-2}\right)\end{array}$ \\
\hline \multirow{4}{*}{ СОМВР } & 0.2 & $0.589 \pm 0.046$ & $0.0223 \pm 0.002$ & $0.0071 \pm 0.0006$ \\
\hline & 0.4 & $3.315 \pm 0.106$ & $0.1254 \pm 0.004$ & $0.0401 \pm 0.0013$ \\
\hline & 0.6 & $5.186 \pm 0.163$ & $0.1961 \pm 0.006$ & $0.0627 \pm 0.002$ \\
\hline & 0.8 & $6.078 \pm 0.182$ & $0.2299 \pm 0.0069$ & $0.0736 \pm 0.0022$ \\
\hline \multirow{4}{*}{ СОМВ } & 0.2 & $0.131 \pm 0.011$ & $0.0050 \pm 0.0004$ & $0.0016 \pm 0.0001$ \\
\hline & 0.4 & $1.118 \pm 0.038$ & $0.0423 \pm 0.0014$ & $0.0135 \pm 0.0005$ \\
\hline & 0.6 & $2.590 \pm 0.084$ & $0.0980 \pm 0.0032$ & $0.0313 \pm 0.0010$ \\
\hline & 0.8 & $3.699 \pm 0.131$ & $0.1399 \pm 0.0049$ & $0.0448 \pm 0.0016$ \\
\hline \multirow{4}{*}{$\mathrm{CCP}$} & 0.2 & $0.493 \pm 0.045$ & $0.0186 \pm 0.0017$ & $0.0060 \pm 0.0005$ \\
\hline & 0.4 & $2.842 \pm 0.106$ & $0.1075 \pm 0.004$ & $0.0344 \pm 0.0013$ \\
\hline & 0.6 & $4.232 \pm 0.104$ & $0.1600 \pm 0.004$ & $0.0512 \pm 0.0013$ \\
\hline & 0.8 & $4.986 \pm 0.135$ & $0.1885 \pm 0.0051$ & $0.0603 \pm 0.0017$ \\
\hline \multirow{4}{*}{$\mathrm{CC}$} & 0.2 & $0.190 \pm 0.016$ & $0.0072 \pm 0.0006$ & $0.0023 \pm 0.0002$ \\
\hline & 0.4 & $1.186 \pm 0.048$ & $0.0448 \pm 0.0018$ & $0.0143 \pm 0.0006$ \\
\hline & 0.6 & $2.386 \pm 0.074$ & $0.0902 \pm 0.0028$ & $0.0289 \pm 0.0009$ \\
\hline & 0.8 & $3.133 \pm 0.096$ & $0.1185 \pm 0.0036$ & $0.0379 \pm 0.0012$ \\
\hline
\end{tabular}
geometric area normalized to square meter $\left(\mathrm{m}^{2}\right)$.

Table 2. HER measurement of MECs based on COMBP, COMB, CCP, and CC anode (Cell potentials).

${ }^{1}$ HER production rate per cubic meter of the anodic medium $\left(\mathrm{m}^{3} \mathrm{~d}^{-1} \mathrm{~m}^{-3}\right) .{ }^{2}$ HER production rate per square meter of electrode $\left(\mathrm{m}^{3} \mathrm{~d}^{-1} \mathrm{~m}^{-2}\right)$.

The results presented in Table 2 show that increasing the applied voltage from $0.2 \mathrm{~V}$ to $0.8 \mathrm{~V}$ resulted in a 10-fold enhancement of the reduction current density in MECs based on plasma-treated anodes (CCP and COMBP), while in MECs based on untreated anodes (CC and COMB) the reduction current density was increased by 28 and 16-fold, respectively. 
The highest hydrogen production rate $\left(0.0736 \pm 0.0022 \mathrm{~m}^{3} \mathrm{~d}^{-1} \mathrm{~m}^{-2}\right.$ at $\left.0.8 \mathrm{~V}\right)$ was obtained in the MEC based on the COMBP anode, which was $40 \%, 18 \%$ and $49 \%$ higher than the MEC based on the $\mathrm{COMB}, \mathrm{CCP}$ and $\mathrm{CC}$ anodes, respectively.

A single-chamber MEC made from narrow-mouth media bottles (total volume of $320 \mathrm{~mL}$, which includes a liquid volume of $100 \mathrm{~mL}$ ) was inoculated with a mixed culture. The anode and cathode were made of carbon cloth, and the cathode was Pt-coated. This MEC was operated under an applied voltage of $1.0 \mathrm{~V}$ and reached a hydrogen production rate of $3.0 \mathrm{~L} \mathrm{~L}^{-1} \mathrm{D}^{-1}$ [52]. A MEC made from wide-mouth glass bottles $(500 \mathrm{~mL})$ was inoculated with a mixed culture. The anode and Pt-coated cathode were made of carbon cloth and separated by a J-cloth. Under an applied voltage of $0.6 \mathrm{~V}$, the MEC reached a hydrogen production rate of $0.53 \mathrm{~m}^{3} \mathrm{day}^{-1} \mathrm{~m}^{3}\left(0.11 \mathrm{~m}^{3} \mathrm{~d}^{-1} \mathrm{~m}^{2}\right)$ at $\mathrm{pH} 7$, and a higher rate of $0.69 \mathrm{~m}^{3} \mathrm{~d}^{-1} \mathrm{~m}^{-3}\left(0.15 \mathrm{~m}^{3} \mathrm{~d}^{-1} \mathrm{~m}^{-2}\right)$ at $\mathrm{pH} 5.8$ [51]. A cubic-shaped single-chamber MEC (liquid volume of $90 \mathrm{~mL}$ ) based on a graphite-fiber brush anode and a carbon-cloth cathode was operated at $4{ }^{\circ} \mathrm{C}$ and $9{ }^{\circ} \mathrm{C}$, which led to a hydrogen production rate varying from $0.23 \pm 0.03$ to $0.53 \pm 0.04 \mathrm{~m}^{3} \mathrm{~d}^{-1} \mathrm{~m}^{-3}$ at an applied voltage of $0.6 \mathrm{~V}$ [53]. A membrane-free MEC (100 mL working volume) consisting of anode and cathode $\left(3 \times 3 \mathrm{~cm}^{2}\right.$ E-Tek carbon cloth without wet-proofing), where the cathode was coated with $0.5 \mathrm{mg} \mathrm{Pt} / \mathrm{cm}^{2}$ and the anode was enriched with exoelectrogens from anaerobic sludge, reached a hydrogen production rate of $0.82 \pm 0.606 \mathrm{~m}^{3} \mathrm{~d}^{-1} \mathrm{~m}^{-3}$ at $1 \mathrm{~V}$. In this MEC, the anode surface area/electrolyte volume ratio was $1850 \mathrm{~m}^{2} \mathrm{~m}^{-3}$ [54]. A tubular single-cell MEC $(28 \mathrm{~mL})$ comprised of a carbon-cloth anode $(3 \mathrm{~cm}$ in diameter, type A without wet-proofing) and a Pt cathode $\left(2 \times 2 \mathrm{~cm}^{2}\right)$ was operated under an applied voltage of $0.6 \mathrm{~V}$, which led to a hydrogen production rate of $2.3 \mathrm{~m}^{3} \mathrm{~d}^{-1} \mathrm{~m}^{-3}$ [55].

3.5. Biofilm Viability Depending on Anode Materials and Plasma Treatment before MEC Construction and after MEC Operation for 30 Days

Examination of G. sulfurreducens ability to produce biofilm on the different anodes was performed before constructing the MEC. The biofilm viability on the different anode material, where the carbon cloth was plasma-treated or untreated, was examined in Geobacter medium and in the presence of a soluble organic electron collector (fumarate). The anodes were incubated for 10 days at $35^{\circ} \mathrm{C}$, followed by MTT analysis, a colorimetric reaction based on the activity of the bacterial oxygenase (Figure 4a). The viability of the bioanodes was also examined at the end of MEC operation (30 days) (Figure 4b).

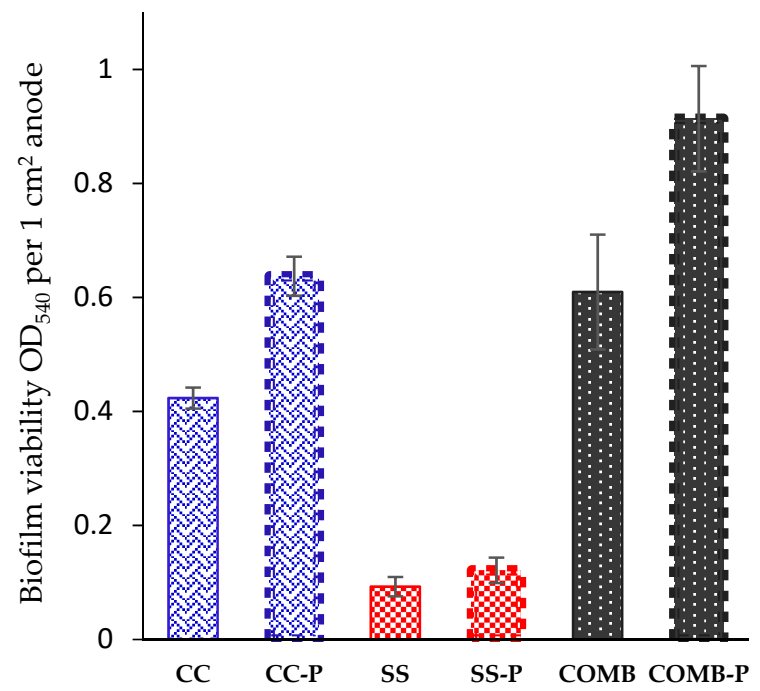

(a)

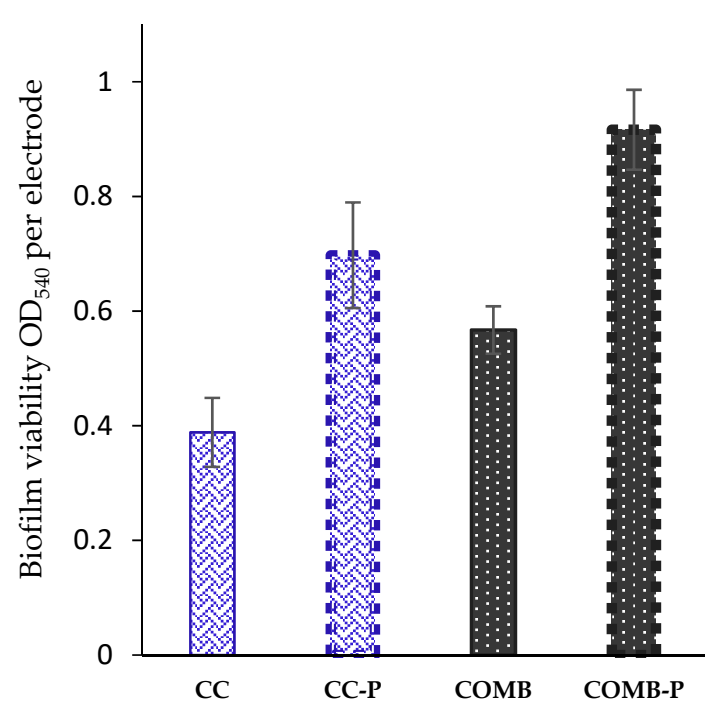

(b)

Figure 4. MTT analysis of biofilm viability on different anode materials CC (图), CCP (\$), SS (\$), SSP (\$), COMB ( COMBP ( $)$ (a) before MEC operation, per $1 \mathrm{~cm}^{2}$ anode; (b) after MEC operation, per electrode. 
As shown in Figure 4a, a higher biofilm viability of about 4-fold was developed on CC $(0.42 \mathrm{OD} \pm 0.02)$ compared to the SS $\left(0.093 \mathrm{OD}_{540} \pm 0.017\right)$. The biofilm viability of CCP was $0.64 \mathrm{OD}_{540} \pm 0.034$, compared to $0.42 \mathrm{OD}_{540} \pm 0.02$ on the untreated CC. Higher biofilm viability was also observed in the combined anode where the carbon cloth was treated by plasma (COMBP), compared to the combined anode where the $\mathrm{CC}$ was untreated (COMB): the biofilm viability was $0.91 \mathrm{OD}_{540} \pm 0.09$ and $0.61 \mathrm{OD}_{540} \pm 0.1$, respectively. The viability of the bioanodes was also examined at the end of the MEC operation. From the results described in Figure $4 b$, it can be seen that the highest biofilm viability as $0.92 \mathrm{OD}_{540} \pm 0.07$ at $\mathrm{OD}_{540}$ was developed on the COMBP anode, compared to $0.57 \mathrm{OD}_{540} \pm 0.04,0.7 \mathrm{OD}_{540} \pm 0.09$, and $0.39 \mathrm{OD}_{540} \pm 0.06$ on the COMB, CCP and CC, respectively. The biofilm viability on the treated anode materials (Figure 4a) and after MEC operation (Figure $4 \mathrm{~b})$ were significantly higher $(p$-value $<0.05)$ compared to the untreated anodes $(\mathrm{CCP} / \mathrm{CC}$; $\mathrm{SSP} / \mathrm{SS}$ and $\mathrm{COMBP} / \mathrm{COMB})$.

Improvement in SS bio-compatibility toward electroactive biofilm was observed in a tubular MEC, when a $316 \mathrm{~L}$ stainless steel-fiber felt anode was pretreated in a furnace at $600{ }^{\circ} \mathrm{C}$ for $5 \mathrm{~min}$ under ambient air pressure [46]. High biofilm attachment was observed on a MEC's SS anode that was modified with polyaniline and polypyrrole, compared to an unmodified SS plate [56]. Stainless steel was cleaned with a mixture of ethanol and acetone to dissolve organic materials, and with a solution of fluoridric/nitric acids to dissolve the oxide layer. Using epifluorescence microscopy, it was shown that the biofilm was densely and well distributed all over the electrode surface [16]. In our recent study, a carbon cloth was exposed to cold nitrogen plasma which resulted by changing its hydrophobic properties. The carbon cloth surface hydrophilicity was measured using a goniometer. It was shown that the contact angle of a water droplet that was placed over the pristine carbon cloth surface was of $\sim 130^{\circ}$. This result indicated that the pristine carbon cloth is a hydrophobic surface. When a water contact angle was measured after cold plasma treatment for $2 \mathrm{~min}$, the contact angle changed to $0^{\circ}$, which is considered as a super-hydrophilic surface. In this case, the improvement of the carbon cloth cathode surface wettability properties improved the mechanical adherence of the catalyst [31]. In our current study, the hydrophilic pattern of the plasma treated carbon cloth anode led to an increasement of the bioanodes biofilm viability and hydrogen evolution rate as shown in Figure 4 and Table 2.

Carbon nanotubes (CNTs) used in MFCs/MECs as anode material $[57,58]$ were treated by plasma and were found to support selective biofilm formation. Enhancement of biofilm formation of Gram-positive bacteria such as S. epidermidis and B. subtilis was displayed on the CNT after plasma treatment. However, the Gram-negative bacteria P. aeruginosa and E. coli responded differently, and their biofilm formation was not affected by the plasma treatment [30]. In another study, a CC anode that was coated by graphene oxide, followed by calcination under an atmospheric-pressure plasma jet, leading to an increase in the surface area as well as in hydrophilicity; consequently, a higher bacterial growth was observed on the treated CC electrode compared to the untreated one [59].

To summarize, examination of plasma treatment on biofilm viability in Geobacter medium containing fumarate as an electron collector showed that on SSP, there was a slight improvement in biofilm viability of $30 \%$ (with a significant $p$-value $<0.05$ ), compared to the untreated SS. It is important to note, however, that plasma treatment led to corrosion of the SS. Contrary to this result, plasma treatment of CC led to a significant increase in biofilm viability, of 50\% and $67 \%$ in CCP and COMBP, respectively, compared to the untreated anodes (CC and COMB). The phenomenon of higher biofilm viability was also observed at the end of MEC operation. The biofilm viability on CCP and COMBP was $80 \%$ and $62 \%$ higher, respectively, compared to the untreated anodes.

\section{Conclusions}

Our single-chamber MECs were constructed using different anode materials: CC, SS, and a combination of these (COMB); along with a platinum-coated CC cathode. The CC and SS anodes were also treated with cold low-pressure nitrogen plasma to improve their surface hydrophilicity, resulting in CCP and SSP, respectively. Plasma treatment led to higher biofilm viability compared to the untreated 
anodes. However, plasma treatment led to corrosion of SSP under an applied voltage of $0.3 \mathrm{~V}$. Thus, the experimental MECs were based on CC, SS, COMB, CCP and COMBP (a combination of SS and CCP) anodes. LSV measurements showed approximately 3-fold increases in currents in the MECs based on $\mathrm{CCP}$ and COMBP, compared to the untreated CC and COMB. An analysis of the contribution of the elements: (biofilm anode, planktonic bacteria, and abiotic electrode) to the overall current obtained in the different MECs showed that the biofilm anode provided the majority of the current density, relative to the other elements. The highest hydrogen production rate $\left(0.0736 \pm 0.0022 \mathrm{~m}^{3} \mathrm{~d}^{-1} \mathrm{~m}^{-2}\right.$ at $\left.0.8 \mathrm{~V}\right)$ was obtained in MECs based on the COMBP anode, which was $40 \%, 18 \%$ and $49 \%$ higher than the MEC based on the COMB, CCP and CC anodes, respectively.

Author Contributions: Conceptualization and methodology, S.R., A.S., and R.C.; contributed to the experiment, S.R.; experimental data analyzing, S.R., B.G.; investigation, L.-O.H.; research administration and supervision, A.S, R.C.; writing—original draft preparation, S.R., A.S., and R.C.; writing—review and editing, L.-O.H., B.G., and R.F. All authors agreed on the final version of the manuscript.

Funding: We would like to thank the Israel Ministry of National Infrastructures, Energy and Water Recourses for the kind support of this work (grant number: 216-11-015).

Conflicts of Interest: The authors declare no conflict of interest.

\section{References}

1. Rabaey, K.; Angenant, L.; Schröder, U.; Keller, J. Bioelectrochemical Systems: From Extracellular Electron Transfer to Biotechnological Application; International Water Association (IWA): London, UK, 2010; ISBN 9781843392330.

2. Bond, D.R.; Lovley, D.R. Electricity production by Geobacter sulfurreducens attached to electrodes. Appl. Environ. Microbiol. 2003, 69, 1548-1555. [CrossRef]

3. Kumar, G.G.; Sarathi, V.G.S.; Nahm, K.S. Recent advances and challenges in the anode architecture and their modifications for the applications of microbial fuel cells. Biosens. Bioelectron. 2013, 43, 461-475. [CrossRef]

4. Zhou, M.; Chi, M.; Luo, J.; He, H.; Jin, T. An overview of electrode materials in microbial fuel cells. J. Power Sources 2011, 196, 4427-4435. [CrossRef]

5. Liu, H.; Hu, H.; Chignell, J.; Fan, Y. Microbial electrolysis: Novel technology for hydrogen production from biomass. Biofuels 2010, 1, 129-142. [CrossRef]

6. Rozenfeld, S.; Schechter, M.; Teller, H.; Cahan, R.; Schechter, A. Novel RuCoSe as non-platinum catalysts for oxygen reduction reaction in microbial fuel cells. J. Power Sources 2017, 362, 140-146. [CrossRef]

7. Schechter, M.; Schechter, A.; Rozenfeld, S.; Emanuel, E.; Cahan, R. Anode Biofilm. In Technology and Application of Microbial Fuel Cells; Wang, C.T., Ed.; InTech: London, UK, 2014; pp. 57-75.

8. Feng, Y.; Yang, Q.; Wang, X.; Logan, B.E. Treatment of carbon fiber brush anodes for improving power generation in air-cathode microbial fuel cells. J. Power Sources 2010, 195, 1841-1844. [CrossRef]

9. Choi, C.; Cui, Y. Recovery of silver from wastewater coupled with power generation using a microbial fuel cell. Bioresour. Technol. 2012, 107, 522-525. [CrossRef]

10. Logan, B.; Cheng, S.; Watson, V.; Estadt, G. Graphite fiber brush anodes for increased power production in air-cathode microbial fuel cells. Environ. Sci. Technol. 2007, 41, 3341-3346. [CrossRef]

11. Aelterman, P.; Versichele, M.; Marzorati, M.; Boon, N.; Verstraete, W. Loading rate and external resistance control the electricity generation of microbial fuel cells with different three-dimensional anodes. Bioresour. Technol. 2008, 99, 8895-8902. [CrossRef] [PubMed]

12. Dewan, A.; Beyenal, H.; Lewandowski, Z. Scaling up Microbial Fuel Cells. Environ. Sci. Technol. 2008, 42, 7643-7648. [CrossRef]

13. Santoro, C.; Arbizzani, C.; Erable, B.; Ieropoulos, I. Microbial fuel cells: From fundamentals to applications. A review. J. Power Sources 2017, 356, 225-244. [CrossRef]

14. Niessen, J.; Schröder, U.; Rosenbaum, M.; Scholz, F. Fluorinated polyanilines as superior materials for electrocatalytic anodes in bacterial fuel cells. Electrochem. Commun. 2004, 6, 571-575. [CrossRef]

15. Benetton, X.D.; Navarro-Ávila, S.G.; Carrera-Figueiras, C. Electrochemical evaluation of Ti/TiO ${ }_{2}$-polyaniline Anodes for Microbial Fuel Cells using Hypersaline Microbial Consortia for Synthetic-wastewater Treatment. J. New Mater. Electrochem. Syst. 2010, 13, 1-6. 
16. Dumas, C.; Basseguy, R.; Bergel, A. Electrochemical activity of Geobacter sulfurreducens biofilms on stainless steel anodes. Electrochim. Acta 2008, 53, 5235-5241. [CrossRef]

17. Pocaznoi, D.; Calmet, A.; Etcheverry, L.; Erable, B.; Bergel, A. Stainless steel is a promising electrode material for anodes of microbial fuel cells. Energy Environ. Sci. 2012, 5, 9645-9652. [CrossRef]

18. Subramanian, P.; Cohen, A.; Teblum, E.; Nessim, G.D.; Bormasheko, E.; Schechter, A. Electrocatalytic activity of nitrogen plasma treated vertically aligned carbon nanotube carpets towards oxygen reduction reaction. Electrochem. Commun. 2014, 49, 42-46. [CrossRef]

19. Bazaka, K.; Jacob, M.V.; Crawford, R.J.; Ivanova, E.P. Plasma-assisted surface modification of organic biopolymers to prevent bacterial attachment. Acta Biomater. 2011, 7, 2015-2028. [CrossRef] [PubMed]

20. Svensson, S.L.; Pryjma, M.; Gaynor, E.C. Flagella-mediated adhesion and extracellular DNA release contribute to biofilm formation and stress tolerance of Campylobacter jejuni. PLoS ONE 2014, 9, e106063. [CrossRef]

21. Scheuerman, T.R.; Camper, A.K.; Hamilton, M.A. Effects of substratum topography on bacterial adhesion. J. Colloid Interface Sci. 1998, 208, 23-33. [CrossRef]

22. Sarjit, A.; Mei Tan, S.; Dykes, G.A. Surface modification of materials to encourage beneficial biofilm formation. AIMS Bioeng. 2015, 2, 404-422. [CrossRef]

23. Wang, X.; Cheng, S.; Feng, Y.; Merrill, M.D.; Saito, T.; Logan, B.E. Use of Carbon Mesh Anodes and the Effect of Different Pretreatment Methods on Power Production in Microbial Fuel Cells. Environ. Sci. Technol. 2009, 43, 6870-6874. [CrossRef]

24. Kolagatla, S.; Subramanian, P.; Schechter, A. Nanoscale mapping of catalytic hotspots on Fe, N-modified HOPG by scanning electrochemical microscopy-atomic force microscopy. Nanoscale 2018, 10, 6962-6970. [CrossRef]

25. Eliezer, Y.; Eliezer, S. The Fourth State of Matter: An Introduction to Plasma Science, 2nd ed.; Institute of Physics Publishing: Bristol, UK, 2001; ISBN 0750307404.

26. Kaplan, S.L.; Rose, P.W. Plasma surface treatment of plastics to enhance adhesion. Int. J. Adhesion Adhes. 1991, 11, 109-113. [CrossRef]

27. Kogelschatz, U. Dielectric-barrier discharges: Their History, Discharge Physics, and Industrial Applications. Plasma Chem. Plasma Process. 2003, 23, 1-46. [CrossRef]

28. Custódio, J.; Broughton, J.; Cruz, H.; Hutchinson, A. A Review of Adhesion Promotion Techniques for Solid Timber Substrates. J. Adhes. 2008, 84, 502-529. [CrossRef]

29. Mujin, S.; Baorong, H.; Yisheng, W.; Ying, T.; Weiqiu, H.; Youxian, D. The surface of carbon fibres continuously treated by cold plasma. Compos. Sci. Technol. 1989, 34, 353-364. [CrossRef]

30. Yick, S.; Mai-Prochnow, A.; Levchenko, I.; Fang, J.; Bull, M.K.; Bradbury, M.; Murphy, A.B.; Ostrikov, K.; Murphya, A.B.; Ostrikov, K. The effects of plasma treatment on bacterial biofilm formation on vertically-aligned carbon nanotube arrays. RSC Adv. 2015, 5, 5142-5148. [CrossRef]

31. Rozenfeld, S.; Teller, H.; Schechter, M.; Farber, R.; Krichevski, O.; Schechter, A.; Cahan, R. Exfoliated molybdenum di-sulfide $\left(\mathrm{MoS}_{2}\right)$ electrode for hydrogen production in microbial electrolysis cell. Bioelectrochemistry 2018, 123, 201-210. [CrossRef]

32. Bormashenko, E.; Chaniel, G.; Grynyov, R. Towards understanding hydrophobic recovery of plasma treated polymers: Storing in high polarity liquids suppresses hydrophobic recovery. Appl. Surf. Sci. 2013, 273, 549-553. [CrossRef]

33. Katz, H.; Farber, R.; Chaniel, G.; Ankar, Y.; Cohen, H.; Cahan, R. Rhamnolipid-enhanced Pseudomonas putida biofilm formation on hydrophilic surfaces with toluene as the bacterium's sole carbon source. Int. Biodeterior. Biodegrad. 2018, 127, 87-94. [CrossRef]

34. Bard, A.J.; Faulkner, L.R. Potential sweep methods, Polarography and pulse voltammetry. In Electrochemical Methods Fundamentals and Applications; John Wiley \& Sons, Inc.: New York, NY, USA, 2001; pp. 226-238, 286-292. ISBN 0471043729.

35. Ribot-Llobet, E.; Nam, J.Y.; Tokash, J.C.; Guisasola, A.; Logan, B.E. Assessment of four different cathode materials at different initial pHs using unbuffered catholytes in microbial electrolysis cells. Int. J. Hydrogen Energy 2013, 38, 2951-2956. [CrossRef]

36. Liu, J.; Zhang, F.; He, W.; Zhang, X.; Feng, Y.; Logan, B.E. Intermittent contact of fluidized anode particles containing exoelectrogenic biofilms for continuous power generation in microbial fuel cells. J. Power Sources 2014, 261, 278-284. [CrossRef] 
37. Marsili, E.; Rollefson, J.B.; Baron, D.B.; Hozalski, R.M.; Bond, D.R. Microbial biofilm voltammetry: Direct electrochemical characterization of catalytic electrode-attached biofilms. Appl. Environ. Microbiol. 2008, 74, 7329-7337. [CrossRef]

38. Asensio, Y.; Montes, I.B.; Fernandez-Marchante, C.M.; Lobato, J.; Cañizares, P.; Rodrigo, M.A. Selection of cheap electrodes for two-compartment microbial fuel cells. J. Electroanal. Chem. 2017, 785, 235-240. [CrossRef]

39. Penteado, E.D.; Fernandez-Marchante, C.M.; Zaiat, M.; Gonzalez, E.R.; Rodrigo, M.A. Influence of carbon electrode materialnfluence of carbon electrode material on energy. Environ. Technol. 2016, 1333-1341.

40. Raschitor, A.; Soreanu, G.; Fernandez-Marchante, C.M.; Lobato, J.; Cañizares, P.; Cretescu, I.; Rodrigo, M.A. Bioelectro-Claus processes using MFC technology: Influence of co-substrate. Bioresour. Technol. 2015, 189, 94-98. [CrossRef]

41. Prestigiacomo, C.; Fernandez-Marchante, C.M.; Fernández-Morales, F.J.; Cañizares, P.; Scialdone, O.; Rodrigo, M.A. New prototypes for the isolation of the anodic chambers in microbial fuel cells. Fuel 2016, 181, 704-710. [CrossRef]

42. Penteado, E.D.; Fernandez-Marchante, C.M.; Zaiat, M.; Gonzalez, E.R.; Rodrigo, M.A.; Penteado, E.D.; Fernandez-Marchante, C.M.; Zaiat, M.; Gonzalez, E.R.; Rodrigo, M.A. Optimization of the performance of a microbial fuel cell using the ratio electrode-surface area / anode-compartment volume. Braz. J. Chem. Eng. 2018, 35, 141-146. [CrossRef]

43. Yamashita, T.; Ishida, M.; Asakawa, S.; Kanamori, H.; Sasaki, H.; Ogino, A.; Katayose, Y.; Hatta, T.; Yokoyama, H. Enhanced electrical power generation using flame-oxidized stainless steel anode in microbial fuel cells and the anodic community structure. Biotechnol. Biofuels 2016, 9, 1-10. [CrossRef]

44. Chen, Y.; Jiang, C.; Cho, C. An Investigation of the compressive behavior of polymer electrode membrane fuel cell's gas diffusion layers under different temperatures. Polymers 2018, 10, 971. [CrossRef]

45. Ul Hassan, N.; Kilic, M.; Okumus, E.; Tunaboylu, B.; Soydan, A.M. Experimental determination of optimal clamping torque for AB-PEM Fuel cell. J. Electrochem. Sci. Eng. 2016, 6, 9. [CrossRef]

46. Guo, K.; Prévoteau, A.; Rabaey, K. A novel tubular microbial electrolysis cell for high rate hydrogen production. J. Power Sources 2017, 356, 484-490. [CrossRef]

47. Erable, B.; Bergel, A. First air-tolerant effective stainless steel microbial anode obtained from a natural marine biofilm. Bioresour. Technol. 2009, 100, 3302-3307. [CrossRef] [PubMed]

48. Guo, K.; Donose, B.C.; Soeriyadi, A.H.; Prévoteau, A.; Patil, S.A.; Freguia, S.; Gooding, J.J.; Rabaey, K. Flame Oxidation of Stainless Steel Felt Enhances Anodic Biofilm Formation and Current Output in Bioelectrochemical Systems. Environ. Sci. Technol. 2014, 48, 7151-7156. [CrossRef] [PubMed]

49. Tartakovsky, B.; Manuel, M.; Wang, H.; Guiot, S. High rate membrane-less microbial electrolysis cell for continuous hydrogen production. Int. J. Hydrogen Energy 2009, 34, 672-677. [CrossRef]

50. Guo, H.; Kim, Y. Scalable multi-electrode microbial electrolysis cells for high electric current and rapid organic removal. J. Power Sources 2018, 391, 67-72. [CrossRef]

51. Hu, H.; Fan, Y.; Liu, H. Hydrogen production using single-chamber membrane-free microbial electrolysis cells. Water Res. 2008, 42, 4172-4178. [CrossRef] [PubMed]

52. Wang, L.; Singh, L.; Liu, H. Revealing the impact of hydrogen production-consumption loop against efficient hydrogen recovery in single chamber microbial electrolysis cells (MECs). Int. J. Hydrogen Energy 2018, 43, 13064-13071. [CrossRef]

53. Lu, L.; Ren, N.; Zhao, X.; Wang, H.; Wu, D.; Xing, D. Hydrogen production, methanogen inhibition and microbial community structures in psychrophilic single-chamber microbial electrolysis cells. Energy Environ. Sci. 2011, 4, 1329-1336. [CrossRef]

54. Verea, L.; Savadogo, O.; Verde, A.; Campos, J.; Ginez, F.; Sebastian, P.J. Performance of a microbial electrolysis cell (MEC) for hydrogen production with a new process for the biofilm formation. Int. J. Hydrogen Energy 2014, 39, 8938-8946. [CrossRef]

55. Hu, H.; Fan, Y.; Liu, H. Hydrogen production in single-chamber tubular microbial electrolysis cells using non-precious-metal catalysts. Int. J. Hydrogen Energy 2009, 34, 8535-8542. [CrossRef]

56. Sonawane, J.M.; Ghosh, P.C.; Adeloju, S.B. Electrokinetic behaviour of conducting polymer modified stainless steel anodes during the enrichment phase in microbial fuel cells. Electrochim. Acta 2018, 287, 96-105. [CrossRef] 
57. Qiao, Y.; Li, C.M.; Bao, S.J.; Bao, Q.L. Carbon nanotube/polyaniline composite as anode material for microbial fuel cells. J. Power Sources 2007, 170, 79-84. [CrossRef]

58. Thepsuparungsikul, N.; Ng, T.C.; Lefebvre, O.; Ng, H.Y. Different types of carbon nanotube-based anodes to improve microbial fuel cell performance. Water Sci. Technol. 2014, 69, 1900-1910. [CrossRef] [PubMed]

59. Chang, S.H.; Liou, J.S.; Liu, J.L.; Chiu, Y.F.; Xu, C.H.; Chen, B.Y.; Chen, J.Z. Feasibility study of surface-modified carbon cloth electrodes using atmospheric pressure plasma jets for microbial fuel cells. J. Power Sources 2016, 336, 99-106. [CrossRef]

(C) 2019 by the authors. Licensee MDPI, Basel, Switzerland. This article is an open access article distributed under the terms and conditions of the Creative Commons Attribution (CC BY) license (http://creativecommons.org/licenses/by/4.0/). 